\title{
APPLICATION OF AEROSPACE DATA FOR FOREST FIRE RISK ASSESSMENT AND PROGNOSES. A CASE STUDY FOR VITOSHA MOUNTAIN
}

\author{
Emiliya Velizarova, Rumen Nedkov, Ibrahim Molla, Mariana Zaharinova
}

\begin{abstract}
An adequate assessment of the fire risk is of great importance for developing fire-prevention policies. Two important indices, that have been frequently used to estimate the level of fire risk, are the Fire Weather Index (FWI) and the Normalized Difference Vegetation Index (NDVI). The main purpose of the present study was to analyse the NDVI index variability during different summer time periods for Vitosha mountain region in order to assess his applicability for accessing the associated risk of fire. A comprehensive spatial and temporal data regarding the distribution of the NDVI index obtained through satellite data (using aerospace technology), GPS and above-ground data, and rationalised using the GIS approach have been applied. The data obtained demonstrate that immediately after a fire, the NDVI for BR "Bistrishko branishte" reached a negative value $-0.025( \pm 0.346)$. The lowest NDVI: $+0.17( \pm 0.339)$ was found for the image taken on 16.08.2012, about two months before the fire occurrence. Overall, the results show that the NDVI data could be successfully used as an indicator for identifying locations with an elevated summer vegetation dryness and provide important information on vegetation sites with an increased fire susceptibility. Therefore development of a fire risk assessment methodology based on using NDVI data, especially during summer periods, appears to be a promising technique for regions, where the fire events have been frequently observed.
\end{abstract}

Key words: Forest fire risk, Vitosha mountain, NDVI, "Bistrishko branishte", "Vitoshko lale"

\section{INTRODUCTION}

Natural disasters, such as floods, forest fires, avalanches, and land-slides result in severe damages causing adverse social, economic and ecological impacts. Therefore, sustainable forest management is of a fundamental importance for combating desertification and for protecting against natural hazards and ensuring regular supplies of essential goods and services to the inhabitants.

The enhanced recreational use of forested areas throughout the world, the continuous growth of forest/urban interfaces, the inadequate public information and awareness, the insufficient policies and the inadequate forest management are some of the key factors leading to increased forest fire risks. These factors have been increasingly contributing to a bigger number of forest fires occurring in Europe during the last decades. Based on the data collected for Europe, more than 50000 forest fires have occurred on areas larger than one hectare each year in the most affected countries, with an annual average of 500000 hectares of burnt forests within the European Union (EU) [1]. In the EU, largespread fires ( $\geq 50$ hectares) account for $75 \%$ of the total burnt area, representing $2.6 \%$ of the total number of all fires. Man-induced forest fires represent about $95 \%$ of this total number.

The climate change clearly exacerbates the current risks of forest fires [2] [3]. Moreover, the climate of Southern Europe including the Mediterranean region is projected to heating at a rate that exceeds the world's global average. Precipitations have been projected to decrease, while the temperature variability, the periods of droughts and the intensity of heat waves have been projected to increase [4]. Respectively, the length and severity of fire seasons, the extension of possible risk areas and the probability of more severe fires occurrence is anticipated to increase [5], [6], [7].

During the last ten years (2004 - 2014), about 87 thousands of hectares on the territory of Bulgaria have been affected by forest fires [8]. The total burned area mapped by the European Forest Fire Information System (EFFIS) in the year 2013 was equal to 252047 ha for the EU28 countries, 36122 ha in the other European countries, and 52390 ha in the North Africa and in the Middle East [9]. It is therefore evident that there is a necessity to prevent as many as possible of these disasters in order to reduce their negative consequences. In year 1979, the European Community first recognised the importance of the problem of forest fires and, since that time, measures of forest protection have been recommended and applied according to dedicated Regulations. The European Commission (EC) and the Standing Forestry Committee decided in 1990 to set-up a Community forest-fire information system in order to monitor the forest fire phenomena at the EU level. A specific Community scheme was approved in 1992 on Monitoring the Health of Forests and Protection of Forests Against Fire with 
the aim of improving the efficiency of the adopted forest-fire protection actions [10].

In 1997, the EC was created a research group to work specifically on development and implementation of advanced methods for evaluation of forest fire risk and estimation of potentially burnt areas within the European territory . Since 1999, this group has been working as a part of the so called "Natural Hazards" project of the European Commission Directorate-General (ECDG) and the Joint Research Centre (JRC). Concerning the fire-prevention phase, the work has been focused on both the development of systems to provide forest fire risk forecast, based of existing fire risk indices, and on the development of new integrated forest fire risk indicators. In 2000, the European Forest Fire Information System (EFFIS) was established by the EC DG Environment and JRC to provide the European institutions and citizens with an almost real time harmonized information on occurring forest fires and their effects, to facilitate international collaboration in forest fire prevention.. Another step forward was done in 2002 with the introduction of maps of forest fire risk at the European level. Within the frame of of the National Fire Danger Rating System (NFDRS) of the US the occurrence of a spreading fire is referred to as "fire risk" [11]. The 'risk' would thereby be the product of the probability of a wildfire and the expected wildfire damages. The chance of fire occurrence, as affected by the nature and incidence of causative agencies, is another available definition of a "fire risk" [12].

Forest fire risk assessment, is based on an integrated index, and thus becomes an important tool for forest fires management. The integrated index includes information about meteorological and other fuel-related variables. Two types of indices are frequently used to estimate the level of fire risk long-term (static) risk indicators and short-term (dynamic) risk indicators. Long-term risk indicators serve to characterize regions subjected to high or low risk of fires, in which the types of variables used for estimation of fire probability are fuel types, topography, and socio-economic factors. Usually, the fuel moisture content is directly connected with the forest fire risk, because a high moisture content increases the heat required to ignite a fuel. Additionally, the most sensible variable for fuel moisture content is based on combination of vegetation indices and surface temperature (Land surface temperature - LST) [13]. The so-called Normalized Difference Vegetation Index (NDVI) refers to dynamic indices that assess the vegetation stress and fire risk. This index is derived by remote sensing data. The peculiar nature of this index permits to assess the role that the vegetation status and/or the specific meteorological conditions play in the assessment of a forest fire risk. Therefore the NDVI and LST indexes have been considered rather useful for forest fire risk assessment [14]. The NDVI has been widely applied to predict fire risk in different regions of the world [15], [16], [17]. However, in Bulgaria, studies on the application of the NDVI so far have been related mainly to assessment of the vegetation degradation in some country regions [18], [19] and the fire scars in the Rila mountain [20]. Therefore the aim of our study was to analyse the NDVI index variability during different summer time periods for the Vitosha region in order to assess the corresponding risk of forest fire.

\section{MATERIALS AND METHODS}

\section{Studied area}

The studied areas are located on the territory of the Biosphere Reserve "Bistrishko branishte" (BRBB), affected by a fire that occurred in July 2012 and on the territory of "Vitoshko lale" (VL), affected by a fire, occurred on October 12, 2012. Both affected by forest fires territories were mapped through on-site measuring of the coordinates using a GPS device. It was calculated that the fire-affected territory of the BRBB was 51.81 ha (based on the onsite measuring of the respective coordinates of 32 points). The delineation of the fire affected territory of "Vitoshko lale" was performed through a GPS device taking the coordinates of 68 points for this site. The fire-affected territory was thus calculated to be equal to 33.68 ha (Fig. 1).

The studied area of Biosphere Reserve "Bistrishko branishte" is located in the territory of the "Vitosha" Natural Park. The total area of this Biosphere Reserve is equal to 1177.2 ha, of which 600 ha are located at an altitude above $1500 \mathrm{~m}$. The main tree type in this area is a natural Norway spruce (Picea abies (L.) Karsten). It was estimated that $13.6 \%$ of the territory of the Biosphere Reserve had been destroyed by a wind-throw on May 22, 2001 [21]. This could lead to decrease the NDVI values, measured before the fire occurrence as prevailing part of vegetation was destroyed. The vegetation cover of the "Vitoshko lale" area is mainly represented by small evergreen shrubs - such as Juniperus sibirica L. and Vaccinium uliginosum L. The altitude of the fire affected area varied from $1856 \mathrm{~m}$ to $1969 \mathrm{~m}$. 

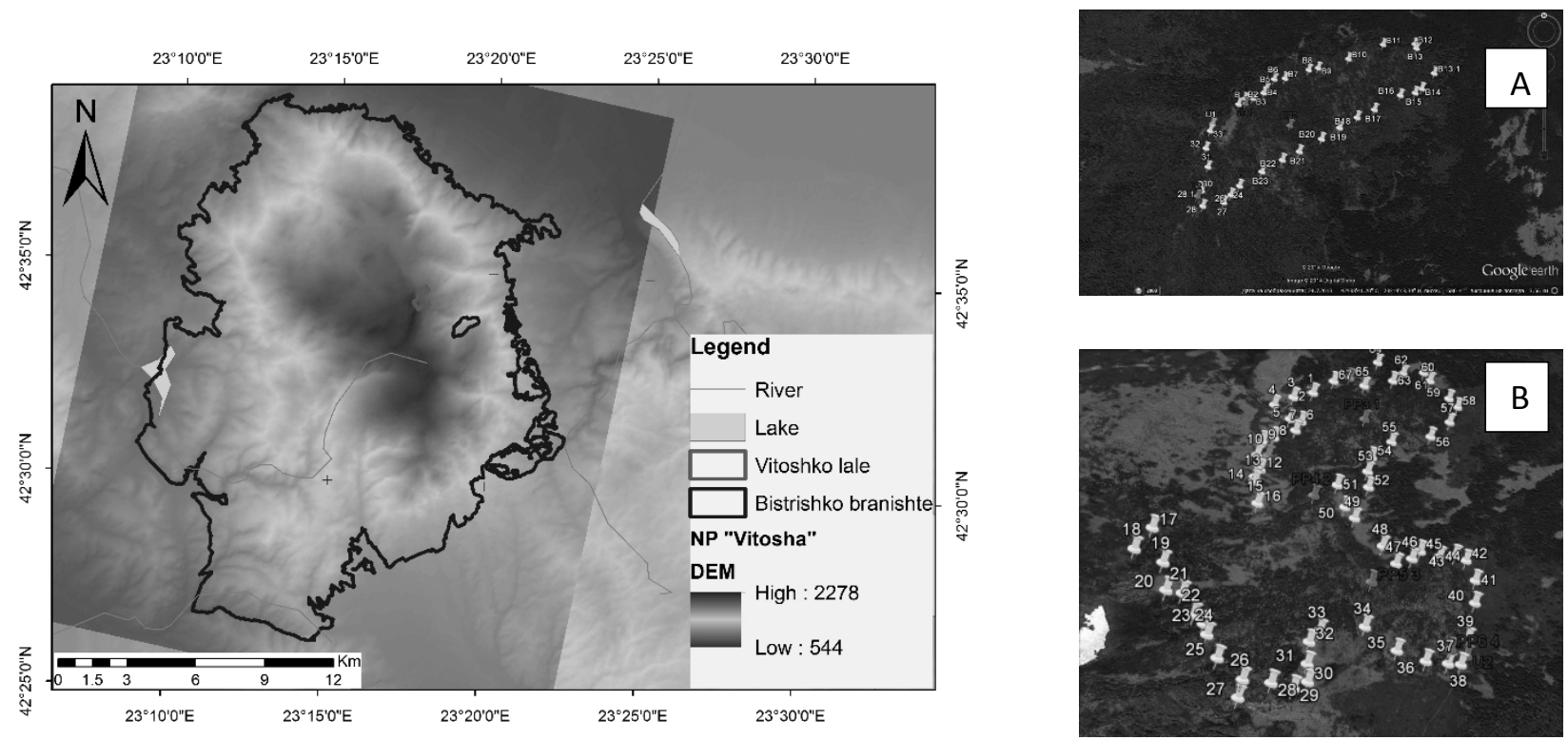

Fig. 1 Location of the studied fire-affected territories in Vitosha mountain A) BR "Bistrishko branishte", B) "Vitoshko lale"

\section{Methodology and data sources}

The Normalized Difference Vegetation Index (NDVI) is a numerical indicator that uses the visible and near-infrared bands of the electromagnetic spectrum, and is adopted to analyse remote sensing measurements and assess whether the target being observed contains live green vegetation or not. Healthy vegetation will absorb most of the visible light that falls on it, and reflects a large portion of the near-infrared light. Unhealthy or sparse vegetation reflects more visible light and less near-infrared light. Bare soils on the other hand reflect moderately in both the red and infrared portion of the electromagnetic spectrum [22]. The behaviour of plants across the electromagnetic spectrum, could be derived from NDVI information by focusing on the satellite bands that are most sensitive to vegetation information (near-infrared and red). The bigger the difference therefore between the near-infrared and the red reflectance, the more vegetation there has to be. The NDVI algorithm subtracts the red reflectance values from the near-infrared and divides it by the sum of nearinfrared and red bands.

The NDVI was calculated according equation 1:

$$
\text { NDVI }=\frac{\left.\mathbb{Z}(\rho]_{\text {NIR }}-\rho_{\text {Red }}\right)}{\mathbb{I}\left(\rho \rrbracket_{\text {NIR }}+\rho_{\text {Red }}\right)}
$$

NDVI $=($ Band TM $4-$ Band TM 3$) /($ Band TM $4+$ Band TM 3),

where: NDVI - Normalized Difference Vegetation Index ; IR - Near Infrared Band - band 4 Landsat TM and ETM+ RED - Red spectral band (visible, Red-band 3 Landsat TM and ETM + )

The NDVI itself varies between -1.0 and +1.0 .

A set of images Landsat $8 \mathrm{TM}$ (with 11 spectral bands at a $30 \mathrm{~m}$ of spatial resolution) were collected from data before and after the occurrence of the forest fire. Three images were acquired in the same season in order to minimize the possible impact of vegetation growth during different seasons (Table 1).

The highest values of NDVI correspond to the white colour on the presented images and were associated with forests in a "good" state. The darkest tones, close to black, show a lack of vegetation, bare soils, or rocks, which absorb the near infrared light more significantly.

\section{RESULTS AND DISCUSSION}

As already mentioned, the risk of forest fires depends on meteorological factors, therefore in this study, we analysed data for the time period with highest summer temperatures and lowest humidity, i.e. between June and October (Table 1).

The mean NDVI values from the images taken during the summer period for the area of BR "Bistrishko branishte" before the fire occurrence were positive and varied between $+0.16(0.474)$ and 
+0.38 (0.403) (Table 2). Immediately after the fire, the NDVI of the image, taken on 16.08.2012 decreased and its mean value was negative $0.025(0.346)$, which confirms the high sensitivity of applying the NDVI approach to analysing forest fire events. During the following two years period, the NDVI values increased gradually to the values, registered for year 2011 - NDVI $+0.29( \pm 0.255)$. This increase of the NDVI after the forest fire c can be attributed to vegetation recovery [18], [19], [20].

Table 1 Summary of the used images data

\begin{tabular}{|c|c|c|c|}
\hline \multirow{2}{*}{ Fire affected area } & \multirow{2}{*}{ Data of fire occurrence } & \multicolumn{2}{|c|}{ Date of used images } \\
\cline { 3 - 4 } & & Before fire & After fire \\
\hline \multirow{2}{*}{$\begin{array}{c}\text { BR "Bistrishko } \\
\text { branishte" } \\
\text { (BRBB) }\end{array}$} & \multirow{2}{*}{01.07 .2012} & 28.06 .2000 & 16.08 .2012 \\
\cline { 3 - 4 } & & 22.08 .2011 & 19.08 .2013 \\
\cline { 3 - 4 } & \multirow{2}{*}{ "Vitoshko lale" (VL) } & 29.06 .2012 & 11.06 .2014 \\
\cline { 3 - 4 } & \multirow{2}{*}{12.10 .2012} & 28.06 .2000 & 19.10 .2012 \\
\cline { 3 - 4 } & & 22.08 .2011 & 11.06 .2013 \\
\hline
\end{tabular}

Table 2. NDVI values for the area of the BR "Bistrishko branishte"

\begin{tabular}{|c|c|c|c|c|c|c|}
\hline \multicolumn{9}{|c|}{ Area of the BR "Bistrishko branishte" influenced by fire on 01.07 2012 } \\
\hline & \multicolumn{3}{|c|}{ NDVI before fire } & \multicolumn{3}{c|}{ NDVI after fire } \\
\hline Data of the image & 28.06 .2000 & 22.08 .2011 & 29.06 .2012 & 16.08 .2012 & 19.08 .2013 & 11.06 .2014 \\
\hline Mean $( \pm$ SD) & $+0.16(0.474)$ & $+0.38(0.403)$ & $+0.325(0.361)$ & $-0.025(0.346)$ & $+0.20(0.282)$ & $+0.29(0.255)$ \\
\hline Min & -0.18 & 0.09 & 0.07 & -0.27 & 0.00 & 0.11 \\
\hline Max & 0.49 & 0.66 & 0.58 & 0.22 & 0.40 & 0.47 \\
\hline
\end{tabular}
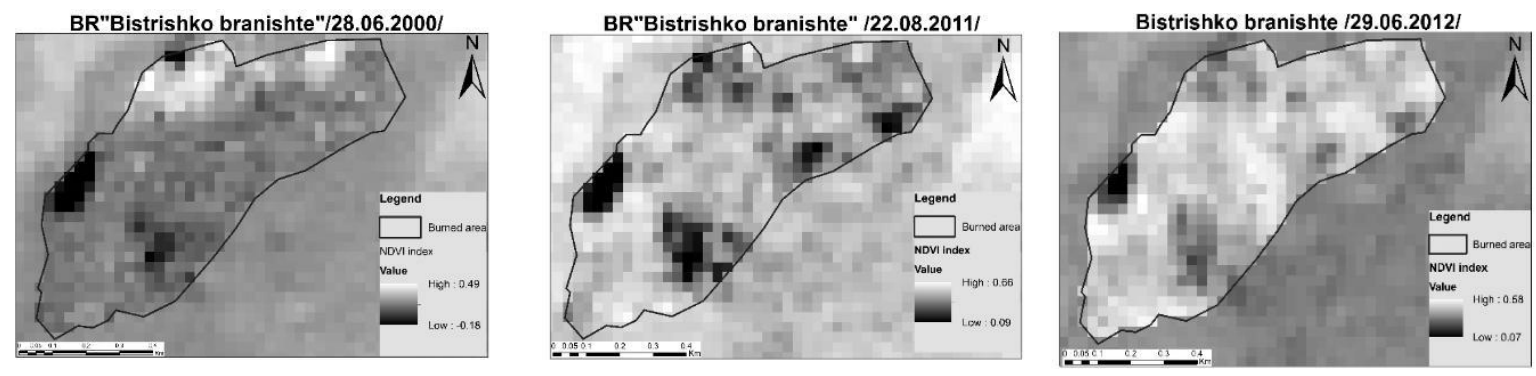

Fig.2. NDVI before the fire occurred on 01.07.2012 on the territory of BR "Bistrishko branishte".
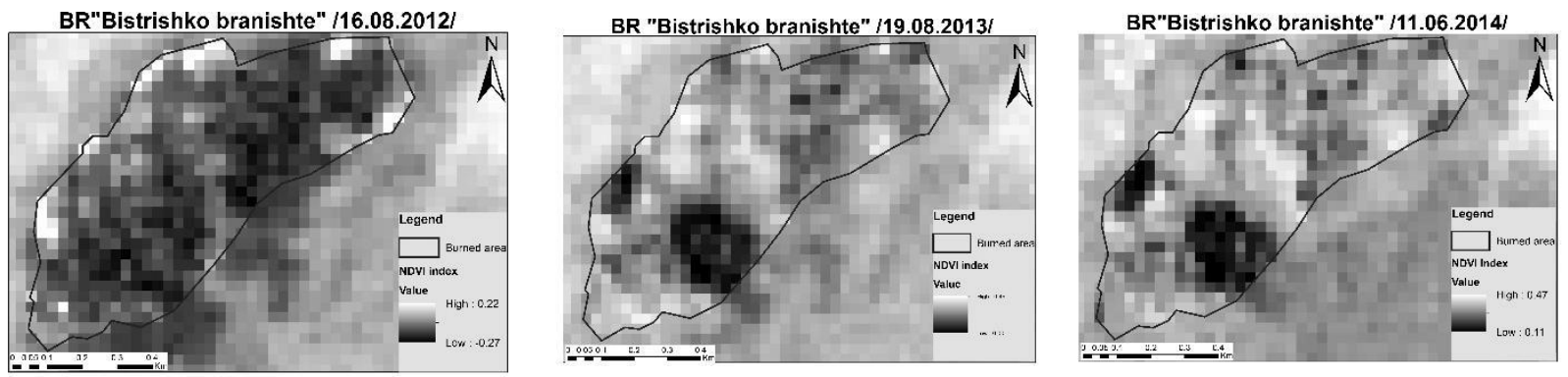

Fig.3. NDVI after the fire occurred on 01.07.2012 on the territory of BR "Bistrishko branishte".

In Fig. 2, the NDVI images represent summer period for 2000, 2011 and 2012 years i.e. period before the fire event on the territory of BRBB. The dark-coloured areas (spots) in Fig. 3 correspond to the images after the forest fire event - from 16.08.2012, 19.08.2013 and 11.06.2014 and show the vegetation zones, which were most influenced by the fire.

As can be seen, all mean values for the NDVI for the "Vitoshko lale" area were found to be positive: from $+0.17(0.339)$ to $+0.43(0.353)$ (Table $3)$. The lowest NDVI: $+0.17(0.339)$ was found for 
the image taken on 16.08.2012, that is about two months before the fire occurrence. As this index is proposed to evaluate the weather impact on vegetation, and, more particularly, the impact of drought [15], [23], it could suggest extreme conditions at the observation date, i.e. a drought or a low photosynthetic activity of vegetation on that day. Such conditions indeed preceded the fire event. A relatively low NDVI of +0.27 (0.304) was found for the image taken on 19.10.2012 - one week after the fire event (12.10. 2012), which was slightly changed during the summer periods of the next two years. Most probably, the fire consequences on the dwarf pine and herbaceous vegetation had been strong and have had a long-term effect. Similar NDVI changes of the newly formed vegetation cover after forest fires has been reported by other authors [19], [20]. The variations of NDVI also depend on plant species and may vary from one year to another in dry climatic conditions [24]. The minimum NDVI was attained during the driest period (AugustSeptember) when the vegetation is in a water-stress state and, thus, the fire susceptibility is expected to be higher.

Table 3. NDVI values for the area of "Vitoshko lale"

\begin{tabular}{|c|c|c|c|c|c|c|c|c|c|c|c|}
\hline \multicolumn{12}{|c|}{ Area of the "Vitoshko lale" influenced by fire on 12.10.2012 } \\
\hline & & & & & & & DVI before $\mathrm{f}$ & & & DVI after fi & \\
\hline \multicolumn{6}{|c|}{ Data of image } & 28.06 .2000 & 22.08 .2011 & 16.08 .2012 & 19.10 .2012 & 19.08.2013 & 11.06 .2014 \\
\hline \multicolumn{6}{|c|}{ Mean $( \pm$ SD) } & $\begin{array}{c}+0.20 \\
(0.424) \\
\end{array}$ & $\begin{array}{c}+0.43 \\
(0.353) \\
\end{array}$ & $\begin{array}{c}+0.17 \\
(0.339) \\
\end{array}$ & $\begin{array}{c}+0.27 \\
(0.304) \\
\end{array}$ & $\begin{array}{c}+0.26 \\
(0.382) \\
\end{array}$ & $\begin{array}{c}+0.29 \\
(0.247) \\
\end{array}$ \\
\hline \multicolumn{6}{|c|}{ Min } & -0.10 & 0.18 & -0.07 & 0.05 & -0.01 & 0.11 \\
\hline Max & 0.5 & 0.68 & 0.41 & 0.48 & 0.53 & \multicolumn{6}{|c|}{0.46} \\
\hline
\end{tabular}
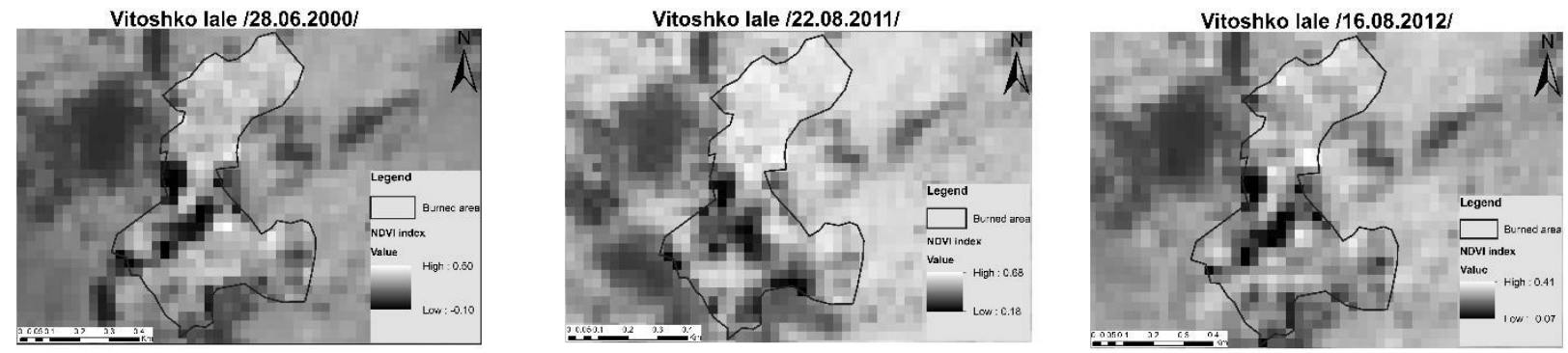

Fig.4. NDVI before fire on 12.10.2012 on the territory of BR "Vitoshko lale".
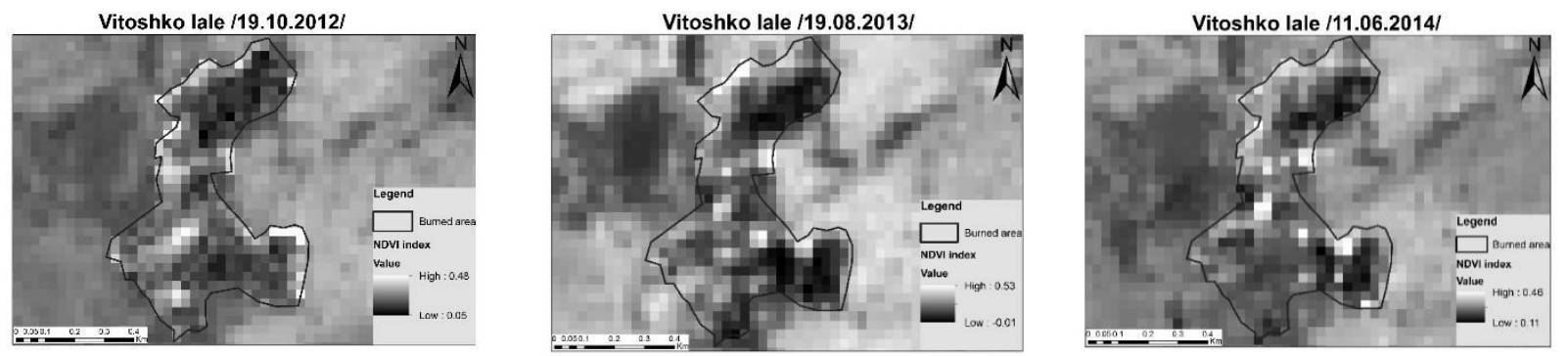

Fig. 5. NDVI after fire on 12.10 .2012 on the territory of BR "Vitoshko lale"

The NDVI image taken on 16.08.2012 - two months before fire occurrence - shows more darkcolored spots, which indicate locations, where the vegetation burnt was more severe (Figure 4). Most probably, these areas had been most sensitive to drought and flame ignition. These results are consistent with the known site characteristics, i.e., climate, elevation and soil types. In any case, the NDVI was found to increase after fire, since the images taken during that period show a slow vegetation recovery (Fig 5).

\section{CONCLUSIONS}

The results obtained in the present study show that aerospace data can be successfully used to calculate the NDVI, evaluate the most vulnerable areas of a summer vegetation dryness and provide important information about fire-susceptible 
vegetation zones. This information can be extremely useful for not easily accessible areas, in which direct terrain observations are either unavailable or rare.

For the investigated areas it may be concluded that the vegetation is strongly influenced by variations of moisture conditions as the temporal NDVI profiles differ between the tree species and between times of observation.

The results demonstrate that immediately after fire, the NDVI for BR "Bistrishko branishte" reached negative value $-0.025(0.346)$. The lowest NDVI $+0.17(0.339)$ was found for the image taken from 16.08.2012, about two months before the fire occurrence.

Overall, it appears that development of a fire risk assessment strategy based on NDVI registration, especially during the summer periods, is a very promising approach for regions, in which the fire events have been proved to be frequent.

\section{References}

1. Assessment of forest fire risk in European Mediterranean region: Comparison of satellitederived and meteorological indices. 2006. Scientific and technical Report by the Joint Research Centre of the European Commission. 2010. 118 p.

2. Fried J.S., M.S. Torn, E. Mills. The impact of climate change on wildfire severity: a regional forecast for northern California. Climatic Change. 2004. 64: 169-91.

3. Bowman D., B. P. Murphy, M. M. Boer, R. A. Bradstock, G. J. Cary, M. A. Cochrane, R.J. Fensham, M.A. Krawchuk, O. F. Price, R. J. Williams. Forest fire management, climate change, and the risk of catastrophic carbon losses. Frontiers in Ecology and the Environment. 2013. 11: 66-67

4. Climate Change and Energy in the Mediterranean. Plan Bleu Regional ActivityCenter. 2008. p. 72. http://media.eib.org/attachments/country/climate cha nge_energy_mediterranean_en.pdf

5. Westerling, A.L. H.G.G. Hidalgo, D.R. Cayan, T.W. Swertman. Warming and earlier spring increases Western US forest fire activity. Science, 2006. 313, p. $940-943$

6. Flannigan, M.D., K.A. Logan, B.D. Amiro, W.R. Skinner, B.J. Stocks. Future area burned in Canada. Climatic Change, 2005, 72, 1-16.

7. Schlyter, P., I. Stjernquist, L. Bärring, A.M. Jönsson and C. Nilsson. Assessment of the impacts of climate change and weather extremes on boreal forests in northern Europe, focusing on Norway spruce. Climate Res., 2006. 31, 75-84.
8. Konstantinov, V. Prevention and protection of forest areas by fires in 2014. Forest. 2015. 3, 12 -13.

9. Forest Fires in Europe, Middle East and North Africa 2013. Technical Report by the Joint Research Centre of the European Commission. 2014. 118 p.

10. Regulation (EC) No 805/2002 of the European Parliament and of the Council of 15 April 2002 amending Council Regulation (EEC) No $2158 / 92$ of 23 July 1992 on protection of the Community's forests against fire

11. Deeming, J., Lancaster, J., Fosberg, M., Furman, R., Shroeder, M., 1972. National fire-danger rating system. Research Paper RM- 84, USDA Forest Service, Rocky Mountain Forest and Range Experiment Station, Fort Collins, CO, 165 pp.

12. FAO. Forestry paper. №70. Wildland fire management terminology. Forestry department. 1986. Roma, $282 \mathrm{p}$.

13. Illera, P., Fernandez, A., Delgado, J. A., Temporal Evolution of the NDVI as an Indicator of Forest Fire Danger. International Journal of Remote Sensing 17: 1093-1105.

14. Verbesselt, J., Fleck, S., Coppin, P., 2002. Estimation of fuel moisture content towards Fire Risk Assessment: A review. Forest fire research and wildland fire safety: Proceedings of IV International Conference on Forest Fire Research / 2002 Wildland Fire Safety Summit, Millpress Press, Luso, Coimbra, Portugal, 2002, 55.

15. Cheret V., J. P. Denux. Mapping wildfire danger at regional scale with an index model integrating coarse spatial resolution remote sensing data. Journal of geophysical research. 2007. VOL. $112,1-11$.

16. Gabban A., J. San $\square$ Miguel $\square$ Ayanz D. X. Viegas. On the suitability of the use of normalized difference vegetation index for forest fire risk assessment. International Journal of Remote Sensing. 2006. V 27 (22), p. 5095-5102

17. Xiaowei LI,FU Guobin, Melanie J. B. ZEPPEL. Probability Models of Fire Risk Based on Forest Fire Indices in Contrasting Climates over China. Journal of Resources and Ecology, 2012, 3(2): 105-117.

18. Stankova, Nedkov, 2015; Stankova N., R. Nedkov . Study of the dynamics of forest vegetation before and after the fire, using aerospace data. Ecological engineering and environment protection. 2015 (1), 40 - 46.

19. Avetisyan, 2015. Avetisyan D. Evaluation of the vegetative cover degradation and erosion processes in the Biosphere reserve "Chuprene reserve (Northwestern Bulgaria ) using methods of remote 
sensing and GIS. Ecological engineering and environment protection. 2015 (1), $47-56$.

20. Dimitrov P, A. Gikov. 2009. Identification and assesment of fire scars in the Rila mountain using spectral indices of landsat data. SENS 2009. Fifth Scientific Conference with International Participation. Space, Ecology, Nanotechnology, Safety, 2-4 November 2009, Sofia, Bulgaria, 142 - 149.

21. Gikov A., Z. Pironkova. Using geoinformation technologies for assessment of tornado damages in forest areas. Scientific Conference "Space, Ecology, Safety" with international participation 10-13 June 2005, Varna, Bulgaria, 269-274.

22. Holme, A. McR., D.G. Burnside, A.A. Mitchell. The development of a system for monitoring trend in range condition in the arid shrublands of Western Australia. Australian Rangeland Journal. 1987. 9:14-20.

23. Kogan, F., A. Gitelson, E. Zakarin, L. Spivak, L. Lebed. AVHRR-based spectral vegetation index for quantitative assessment of vegetation state and productivity: Calibration and validation, Photogramm. Eng. Remote Sens. 2003, 69(8), 899906.

24. Reed, B. C., J. F. Brown, D. VanderZee, T. R. Loveland, J. W. Merchant, D. O. Ohlen. Measuring phenological variability from satellite imagery, J. Veg. Sci., 2004. 5, 703- 714.

\title{
ПРИЛОЖЕНИЕ НА АЕРОКОСМИЧЕСКИ МЕТОДИ ЗА ПРОГНОЗИРАНЕ И ОЦЕНКА НА РИСКА ОТ ГОРСКИ ПОЖАРИ. НА ПРИМЕРА НА ИЗСЛЕДВАНИЯ, ПРОВЕДЕНИ В ПЛАНИНАТА ВИТОША
}

\author{
Емилия Велизарова, Румен Недков, Ибрахим Молла, Мариана Захаринова
}

\begin{abstract}
Резюме. Оценката на риска от пожари е от голямо значение при изготвянето на политики за превенция. Двата основни индекса, които се използват най-често за определяне на нивото на риск от пожари са индексьт за времето (Fire Weather index - FWI), определян въз основа на прогнозата за времето и сателитни изображения и вегетационния индекс - NDVI. Цел на изследването е да анализира променливостта на индекса NDVI през летните месеци за региона на Витоша, за да се оцени приложимостта им за оценка на риска от пожар. Проведен е сравнителен анализ на разпределението на NDVI индекса през определени периоди от време със сателитни данни с помощта на космически технологии и експериментално-получени данни на място от засегнатите от пожари територии чрез използване на ГИС. Получените данни показват, че веднага след пожар, стойностите за NDVI за BR „Бистришко бранище“ има отрицателна стойност -0.025 ( \pm 0.346$)$. Най-ниската NDVI от 0.17 $( \pm 0.339)$ е установено за изображението, направено на 16.08.2012 - около два месеца преди настъпването пожара. Резултатите показват, че данните за NDVI могат да се използват успешно като показател за идентифициране на места с повишено засушаване за растителността през летния сезон, както и да предоставят важна информация за местата, на които растителността е с повишена чувствителност по отношение на пожар. Ето защо създаването на методология за оценка на риска от пожари основаваща се на използването на данни за NDVI, особено през летните месеци е обещаващ метод за райони, където пожарите са често явление.
\end{abstract}

Ключови думи: оценка на риск от пожари, Витоша, NDVI, “Бистришко бранище”, “Витошко лале”

\section{Емилия Велизарова}

Институт за гората - БАН

Бул. Кл. Охридски 132

1756 София, България

e-mail: velizars@abv.bg

проф. д-р Румен Недков

Институт за космически изследвания и технологии - БАН

ул. Акад. Г. Бончев 1

София 1113

e-mail: rnedkov@space.bas.bg

\author{
Emiliya Velizarova \\ Forest Research Institute - \\ Bulgarian Academy of Sciences \\ 132 St.K. Ohridski Blvd. \\ 1756 Sofia, Bulgaria \\ e-mail: velizars@abv.bg
}

Prof. Dr. Roumen Nedkov

Space Research and Technology Institute -

Bulgarian Academy of Sciences

Acad. Georgi Bonchev Str., B1. 1

Sofia 1113, Bulgaria

e-mail: rnedkov@s,space.bas.bg 


\section{Ибрахим Молла}

Институт за гората - БАН

бул. Кл. Охридски 132

1756 София, България

e-mail: mollata@abv.bg

\section{Мариана Захаринова}

Институт за космически изследвания и технологии - БАН

ул. Акад. Г. Бончев, бл.1

София 1113

e-mail: marianaz@space.bas.bg

\section{Ibrahim Molla}

Forest Research Institute -

Bulgarian Academy of Sciences

132 St.K. Ohridski Blvd.

1756 Sofia, Bulgaria

e-mail: mollata@abv.bg

\section{Mariana Zaharinova}

Space Research and Technology Institute Bulgarian Academy of Sciences

Acad. Georgi Bonchev Str., B1.1

Sofia 1113, Bulgaria

e-mail: marianaz@space.bas.bg 